\title{
Comparison of avifaunal diversity in and around Neora Valley National Park, West Bengal, India
}

\author{
Utpal Singha Roy ${ }^{1}$, Arijit Pal ${ }^{2}$, Purbasha Banerjee ${ }^{3}$ \& Subhra Kumar \\ Mukhopadhyay ${ }^{4}$ \\ ${ }^{1}$ Department of Zoology, ${ }^{2,3}$ Department of Conservation Biology, Durgapur Government College, JN Avenue, Durgapur, West \\ Bengal 713214, India \\ ${ }^{4}$ Hooghly Mohsin College, Chinsurah, West Bengal 712101, India \\ Email: ${ }^{1}$ srutpal@gmail.com (corresponding author), ${ }^{2}$ arijitpal1988@gmail.com, ${ }^{3}$ banerjeepurbasha@gmail.com, ${ }^{4}$ msubhro@yahoo.com
}

\begin{abstract}
Anthropogenic intervention has led to conversion of much of the global diversity by means of habitat alterations. The present study was carried out to investigate the importance of habitat quality and habitat heterogeneity for the diversity, distribution and abundance of avifauna in and around Neora Valley National Park (NVNP) during April-May 2010. A total of 73 bird species belonging to 25 families were recorded during the present study applying a modified point count method. Forest edges were found to be most diverse with a total count of 54 bird species having an abundance of 172.53 number of birds ha- ${ }^{1}$. Study areas with human settlements was represented by a total species count of 24 with an abundance of 130.39 number of birds ha- ${ }^{-1}$ while a total species count of 22 with an abundance of 69.32 number of birds ha- ${ }^{1}$ was recorded from thick vegetation assemblage with close canopy cover. This site specific occurrence pattern for avifauna was reflected in the study of diversity indices. The highest Shannon-Wiener general diversity score of 3.77 was recorded for bird species from forest edges. Study areas with dense canopy closure were found to support more habitat specialist bird species while areas having human settlements harboured more opportunistic bird species. An overall negative influence of human settlements on bird diversity, distribution and abundance was evidenced from the present study and needs further investigation. Moreover, intensive studies will certainly enrich our knowledge of avian diversity and distribution pattern from the present study location.
\end{abstract}

Keywords: Avifauna, diversity indices, hotspot, Lava, Neora Valley National Park.

Date of publication (online): 26 October 2011

Date of publication (print): 26 October 2011

ISSN $0974-7907$ (online) | 0974-7893 (print)

Editor: Rajiv S. Kalsi

Manuscript details:

Ms \# 02542

Received 11 August 2010

Final received 28 August 2011

Finally accepted 27 September 2011

Citation: Roy, U.S., A. Pal, P. Banerjee \& S.K. Mukhopadhyay (2011) Comparison of avifaunal diversity in and around Neora Valley National Park, West Bengal, India. Journal of Threatened Taxa 3(10): 2136-2142.

Copyright: (c) Utpal Singha Roy, Arijit Pal, Purbasha Banerjee, Subhra Kumar Mukhopadhyay 2011. Creative Commons Attribution 3.0 Unported License. JoTT allows unrestricted use of this article in any medium for non-profit purposes, reproduction and distribution by providing adequate credit to the authors and the source of publication.

Acknowledgements: The authors are thankful to the Director of Public Instuction, Government of West Bengal and Divisional Forest Manager Kalimpong, West Bengal for their kind help and cooperation.

OPEN ACCESS | FREE DOWNLOAD

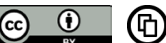

Neora Valley National Park (NVNP), is a compact patch of virgin forest located in the Eastern Himalaya, is a global 'Biodiversity Hotspot'. The northern and northeastern boundaries of NVNP are contiguous with Sikkim and Bhutan, respectively, and link the Pangolakha Wildlife Sanctuary in Sikkim. The southern boundaries of NVNP are remotely connected with the Chapramari Wildlife Sanctuary and the Gorumara National Park. NVNP belongs to an Important Bird Area (IBA Site code: IN-WB-06 under the IBA criteria: A1 (threatened species), A2 (endemic bird area) and 130: Eastern Himalaya. According to Islam \& Rahmani (2004), Prakriti Samsad has recorded 288 species of birds from Lava and Loleygoan ranges which are adjacent to this National Park. Relationship between habitat and bird diversity has been reported by Chettri et al. (2005) from western Sikkim. The present study attempts to prepare a checklist of birds to compare bird diversity of closed canopy covered areas of NVNP, its edges and of the areas where forests are subjected to various degrees of pressure from human disturbances.

\section{Study Area}

Three contrasting forest patches were chosen in the present study depending upon the complexity of habitat structure. A thick vegetation assemblage with close canopy cover, edges of forests, and areas with human settlements in and around NVNP were studied for bird diversity and has been referred to as study area

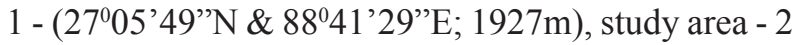
(2706'01'N \& 88 40'33"E; 1612m) and study area $3\left(27^{\circ} 05^{\prime} 11^{\prime \prime} \mathrm{N} \& 88^{0} 39^{\prime} 41^{\prime \prime} \mathrm{E} ; 2061 \mathrm{~m}\right)$ in the present investigation (Image 1). Study area - 3 was located adjacent to a hill station Lava, a place of major tourist attraction in northern Bengal. Intense anthropogenic influence, both direct and indirect was evident in this 


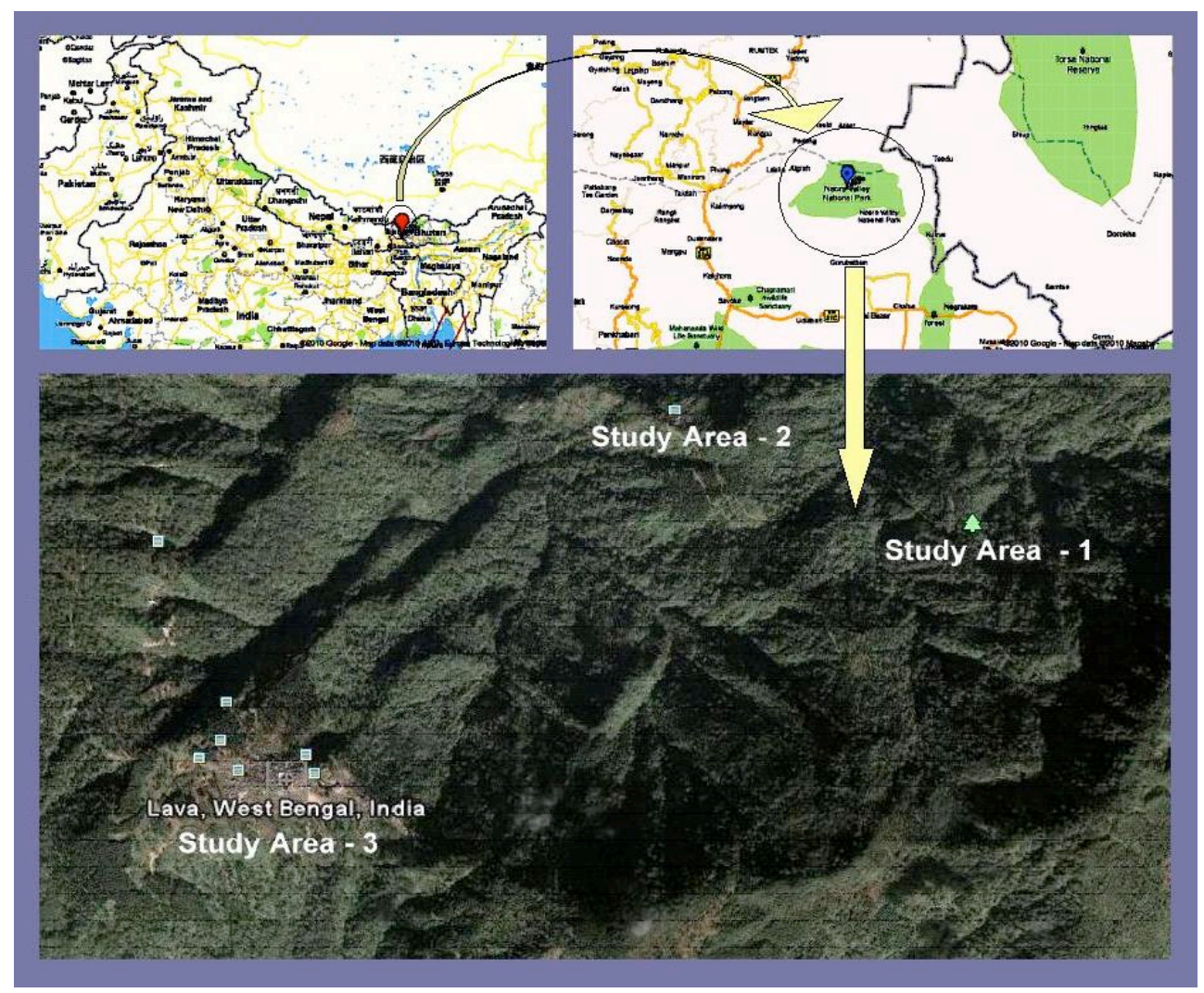

Image 1. Map of the three study areas in and around Neora Valley National Park.

area. Much of the forest has already been destroyed here and ever increasing tourism pressure is engulfing the remains.

Neora Valley was notified as a national park in the year 1992 based on the provisions of the Wildlife (Protection) Act 1972 and covers two biomes, the SinoHimalayan temperate forest (Biome-7) from 1800 to $3600 \mathrm{~m}$ elevation and the Sino-Himalayan subtropical forest (Biome-8) from 1000 to $2000 \mathrm{~m}$ elevation (Islam \& Rahmani 2004). The phytogeography of NVNP consists of the subtropical broadleaf hill forest, montane wet temperate forest and subtropical pine forest (Champion \& Seth 1968). According to Rodgers et al. (2002) NVNP lies in the bio-geographic zone 2. Floral and faunal composition of NVNP typically represents that of oriental regions with high endemism. Human settlements around this protected area have altered the biodiversity due to habitat degradation. This region is a major tourist attraction and the consequent disturbances coupled with the pressure for livelihood of local people is forcing the conversion of this well known birders' paradise.

\section{Methods}

Sutherland (2006) recommended point count as the most efficient method for estimating avian abundance from mixed habitat types. Since the present study site was mostly heterogeneous, a total of 162 point counts (nine counts on each day for six consecutive days at three sites) during the first two hours after sunrise (0600-0800 hr), during noon (1100-1300 hr) and in the evening (1600-1800 hr) between the 29 April and 04 May 2010 were carried out. We selected a grid of nine points in each study site and adjacent points were $200 \mathrm{~m}$ apart. Counting of birds in bands of 30 and $50 \mathrm{~m}$ has been recommended for close forest and open habitat areas (Sutherland 2006). In the present study a fixed radius (always at a distance between 30 and $40 \mathrm{~m}$ ) circular-plot method was used. At each individual point count, observations were made for 10 minutes for all the birds seen (perched or flying under the canopy) and photographed if not identified immediately. Birds seen or heard within the fixed radius plot were counted separately from those detected outside the plot. Ali (1996), Grimmett et al. (1998) 
and Kazmierczak \& Perlo (2000) were followed for identification. Avifaunal density was calculated by applying the formula: Avifaunal density, $\check{D}=\left(n_{1}+n_{2}\right.$ $\left./ \pi r^{2} m\right) \ln \left(n_{1}+n_{2} / n_{2}\right)$ (where, $r=$ radius of concentric zone from the point of observation (30 and $40 \mathrm{~m}) ; \mathrm{n}_{1}=$ number of birds counted within $\mathrm{r} ; \mathrm{n}_{2}=$ number of birds counted beyond $\mathrm{r} ; \mathrm{m}=$ number of replicate counts) following Henderson (2003). Shannon-Wiener index of diversity $\left(\mathrm{H}^{\prime}\right)$, Pielou's evenness index $\left(\mathrm{J}^{\prime}\right)$, Margalef's richness index $\left(\mathrm{D}_{\text {MARG }}\right)$ and Simpson's dominance index $\left(\mathrm{D}_{\text {SIMP }}\right)$ were calculated to analyze the avian community structure using PAST statistical software (Pandya \& Vachhrajani 2010). Although both Shannon measures and Simpson's index consider the proportional abundances of species, $\mathrm{H}^{\prime}$ is more sensitive to rare species, whereas $\mathrm{D}_{\text {SIMP }}$ puts greater emphasis on common species. On the other hand, Margalef's richness index $\left(\mathrm{D}_{\text {MARG }}\right)$, considers both abundances and species numbers whereas Pielou's evenness index $(\mathrm{J} /)$ considers abundance and species occurrence pattern. Therefore, combinations of these indices were used to comment on the diversity of avifaunal community from the present study locations. Hierarchical cluster analysis was done to construct a dendrogram for commenting on the relation between the study areas, using SPSS 13.0.

\section{Results}

A total of 73 bird species belonging to 25 families were recorded during the short period of the present study (Appendix 1). Family-wise distribution of all the bird species varied widely among all three study sites, with Muscicapidae having the highest representatives followed by Corvidae. The highest bird diversity was recorded in study area - 2 (total species count of 54 with an abundance of 172.53 birds ha $^{-1}$ ) followed by study area - 1 (total species count of 24 with an abundance of 130.39 birds ha $^{-1}$ ) and study area - 3 (total species count of 22 with an abundance of 69.32 birds ha $\left.{ }^{-1}\right)$. Figure 1 represents the co-occurrence of birds among the three study sites. The transition zones between study area - 1 and study area - 2 , study area 2 and study area - 3 and study area - 1 and study area - 3 were represented by 17 , nine and five bird species, respectively. Only five bird species were found at the same time in all three sites. All the diversity indices studied in the present investigation were higher in study area - 2 with $\mathrm{H}^{\prime}, \mathrm{D}_{\text {SIMP, }} \mathrm{J}^{\prime}$ and $\mathrm{D}_{\text {MARG }}$ scores of $3.77,0.97$,

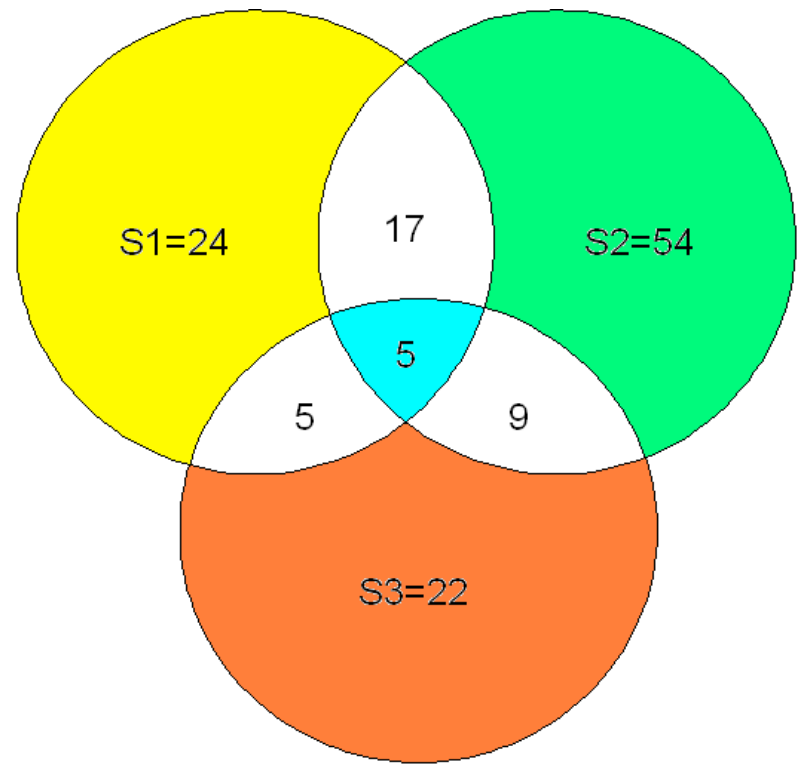

Figure 1. Graphical presentation of all the bird species from the three study sites (SA 1, $2 \& 3$ ) based on commonality of occurrence.

Table 1. Diversity indices for the three study areas (SA 1, 2 \& 3) in and around Neora Valley National Park.

\begin{tabular}{|l|c|c|c|}
\hline Diversity indices & SA - 1 & SA - 2 & SA - 3 \\
\hline Shannon-Wiener Diversity Index & 2.639 & 3.767 & 2.865 \\
\hline Simpson's Dominance Index & 0.898 & 0.972 & 0.929 \\
\hline Pielou's Evenness Index & 0.584 & 0.801 & 0.798 \\
\hline Margalef's Richness Index & 4.722 & 10.290 & 4.954 \\
\hline
\end{tabular}

Dendrogram using Average Linkage (between groups) Rescaled Distance Cluster Combine

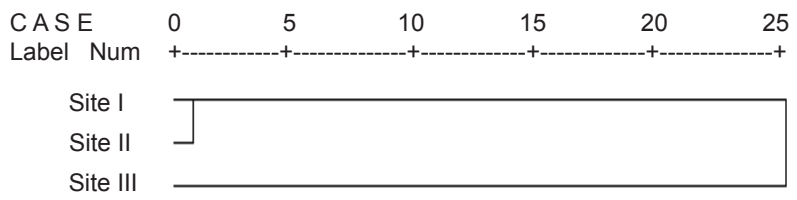

Figure 2. Dendrogram showing the relationship between the three study areas where study area - 1 and study area 3 with relatively lesser avian diversity were found to form a close cluster.

0.80 and 10.29 respectively (Table 1). Diversity index values recorded from study area - 1 and study area -3 were comparable with $\mathrm{H}^{\prime}, \mathrm{D}_{\mathrm{SIMP}} \mathrm{J}^{\prime}$ and $\mathrm{D}_{\mathrm{MARG}}$ scores of 2.64 and $2.86,0.90$ and $0.93,0.58$ and 0.80 and 4.72 and 4.95, respectively. Dendrogram, constructed from hierarchical cluster analysis showed that study area - 1 and study area - 3 were nearer to each other while the most diverse forest edges of study area - 2 was the farthest (Fig. 2). 


\section{Discussion}

Conservationists around the globe are facing great challenges under the mounting threats of anthropogenic disturbances to biodiversity. Moreover, holistic inventory of diversity requires nearly impossible levels of time and effort. Considering these factors, shortspan study of biota for overall biodiversity estimation is of great importance and of late much emphasis has been given to prepare checklists of birds on a wider scale (Chakravarthy \& Sridhar 1995).

This study indicated a greater diversity of birds in forestedges when compared to dense forest patches with closed canopy covers and in areas with anthropogenic settlements and these finding is similar to Aich \& Mukhopadhyay (2008). Edges of forests were found to contain both habitat generalist and habit specialist birds while dense canopy closure supported more of habitat specialist avian species like, Spot-bellied Eagle Owl Bubo nipalensis while areas under anthropogenic influence harboured more of opportunistic bird species. Distribution wise, only five bird species were found to be co-occurring in all three study sites. This habitat specific distribution of avifauna was reflected in the study of diversity indices where all the indices were higher in areas of forest edges. Avifaunal diversity and abundance in canopy closure were higher than in areas with human settlements but diversity index scores of both the study areas were comparable. This was also reflected in the dendrogram where the most diverse forest edges (study area - 2) were located separately from the cluster of study area - 1 and study area -3 . This may be attributed to the fact that although both Shannon measures $\left(\mathrm{H}^{\prime}\right)$ and Simpson's index $\left(\mathrm{D}_{\text {SIMP }}\right)$ consider the proportional abundance of species, $\mathrm{H}^{\prime}$ is more sensitive to rare species, whereas $\mathrm{D}_{\text {SIMP }}$ puts emphasis on the common species. Species evenness in homogeneous forest edges was higher, and was followed by areas under anthropogenic influence and closed canopy cover. This may be due to the fact that canopy closure supports more specialist species with restricted distribution pattern and narrow niche width while areas under anthropogenic intervention support even distribution of generalist and opportunistic bird species that can exploit the available resources with an overlapping pattern of niche width. Anthropogenic disturbances on forest structure and function are well on record (Bhat \& Murali 2001; Chandrashekara et al.
2006) and present findings also indicated a negative influence of anthropogenic intervention on overall bird diversity.

The present investigation recorded one globally vulnerable species, the Beautiful Nuthatch Sitta formosa. This species has been referred to as Vulnerable [C2a(i)] by BirdLife International (2010) IUCN Red List (2011) for birds, due to its small, declining and highly fragmented population size. Conservation measures have been taken for this species in adjacently located Buxa Tiger Reserve and we would like to propose NVNP to be designated for the same cause. We would also like to mention that the current investigation included a vagrant bird, Water Pipit Anthus spinoletta, a new record from this part of the world.

Our short-term study involved only a few selected patches of forests; a more intensive study might yield many more species. Detailed studies might improve the list of avian species and their characteristic distribution in different forest patches from the present location. The impact of anthropogenic alteration of the habitats in and around Neora Valley National Park also needs further intensive studies.

\section{REFERENCES}

Aich, A. \& S.K. Mukhopadhyay (2008). Comparison of avifauna at the edges of contrasting forest patches in Western Ghat hills of India. Ring 30(1): 5-14.

Ali, S. (1996). The Book of Indian Birds. Bombay Natural History Society, Bombay, 354pp.

Bhat, D.M. \& K.S. Murali (2001). Phenology of understorey species of tropical moist forest of Western Ghats region of Uttara Kannada District in South India. Current Science 81(7): 799-805.

BirdLife International (2010). IUCN Red List for Birds. http:// www.birdlife.org/. Accessed on 17 December 2010.

Champion, H.G. \& S.K. Seth (1968). A Revised Survey of the Forest Types of India. Government of India, New Delhi, 404pp.

Chandrashekara, U.M., P.K. Muraleedharan \& V. Sibichan (2006). Anthropogenic pressure on structure and composition of a shoal forest in Kerala. Indian Journal of Mountain Science 3(1): 58-70.

Chakravarthy, A.K. \& S. Sridhar (1995). Bird Diversity and Conservation. Ornithological Society of India, Bangalore, 19-31pp.

Chettri, N., D.C. Deb, E. Sharma \& R. Jackson (2005). The relationship between bird communities and habitat a study 
Appendix 1. Checklist of birds along with their status and abundance (number ha-1) for the three study areas (SA 1, $2 \& 3)$ in and around Neora Valley National Park.

\begin{tabular}{|c|c|c|c|c|c|c|}
\hline & Family / Common name & Scientific name & Status & SA - 1 & SA - 2 & SA - 3 \\
\hline & Picidae & & & & & \\
\hline \multirow[t]{2}{*}{1} & Greater Yellownape & Picus flavinucha & $\mathrm{R}$ & 0.00 & 1.95 & 1.95 \\
\hline & Cuculidae & & & & & \\
\hline 2 & Common Hawk Cuckoo & Hierococcyx varius & $\mathrm{R}$ & 0.59 & 2.10 & 0.00 \\
\hline \multirow[t]{2}{*}{3} & Drongo Cuckoo & Surniculus lugubris & $S$ & 0.00 & 1.95 & 0.00 \\
\hline & Centropodidae & & & & & \\
\hline \multirow[t]{2}{*}{4} & Lesser Coucal & Centropus bengalensis & $\mathrm{R}$ & 0.00 & 1.95 & 0.00 \\
\hline & Psittacidae & & & & & \\
\hline \multirow[t]{2}{*}{5} & Red-breasted Parakeet & Psittacula alexandri & $\mathrm{R}$ & 0.00 & 0.00 & 2.12 \\
\hline & Apodidae & & & & & \\
\hline \multirow[t]{2}{*}{6} & Asian Palm Swift & Cypsiurus balasiensis & $\mathrm{R}$ & 0.00 & 0.00 & 1.84 \\
\hline & Strigidae & & & & & \\
\hline \multirow[t]{2}{*}{7} & Spot-bellied Eagle Owl & Bubo nipalensis & V & 1.95 & 0.00 & 0.00 \\
\hline & Columbidae & & & & & \\
\hline 8 & Oriental Turtle Dove & Streptopelia orientalis & $\mathrm{R}$ & 19.16 & 3.41 & 2.16 \\
\hline 9 & Spotted Dove & Streptopelia chinensis & $\mathrm{R}$ & 0.00 & 0.00 & 2.63 \\
\hline \multirow[t]{2}{*}{10} & Barred Cuckoo Dove & Macropygia unchall & $\mathrm{R}$ & 1.95 & 0.00 & 0.00 \\
\hline & Accipitridae & & & & & \\
\hline 11 & Black Kite & Milvus migrans & $\mathrm{R}$ & 0.00 & 0.00 & 0.70 \\
\hline \multirow[t]{2}{*}{12} & Crested Serpent Eagle & Spilornis cheela & $\mathrm{R}$ & 0.00 & 0.26 & 0.00 \\
\hline & Threskiornithidae & & & & & \\
\hline \multirow[t]{2}{*}{13} & Black Ibis & Pseudibis papillosa & $\mathrm{R}$ & 0.00 & 0.00 & 2.12 \\
\hline & Lanidae & & & & & \\
\hline \multirow[t]{2}{*}{14} & Long-tailed Shrike & Lanius schach tricolor & $S$ & 0.00 & 1.18 & 0.00 \\
\hline & Corvidae & & & & & \\
\hline 15 & Yellow-billed Blue Magpie & Urocissa erythrorhyncha & $\mathrm{R}$ & 6.56 & 0.00 & 0.00 \\
\hline 16 & House Crow & Corvus splendens & $\mathrm{R}$ & 0.00 & 0.00 & 5.58 \\
\hline 17 & Large-billed Crow & Corvus macrorhynchos & $\mathrm{R}$ & 4.20 & 2.51 & 2.94 \\
\hline 18 & Common Raven & Corvus corax & $\mathrm{R}$ & 1.95 & 1.95 & 0.00 \\
\hline 19 & Scarlet Minivet & Pericrocotus flammeus & $\mathrm{R}$ & 1.94 & 4.10 & 0.00 \\
\hline 20 & Yellow-bellied Fantail & Rhipidura hypoxantha & $S$ & 1.95 & 0.00 & 0.00 \\
\hline 21 & White-browed Fantail & Rhipidura aureola & $\mathrm{R}$ & 0.00 & 1.95 & 0.00 \\
\hline 22 & Black Drongo & Dicrurus macrocercus & $\mathrm{R}$ & 0.00 & 1.40 & 3.76 \\
\hline \multirow[t]{2}{*}{23} & Lesser Racket-tailed Drongo & Dicrurus remifer & $\mathrm{R}$ & 0.00 & 0.00 & 2.12 \\
\hline & Muscicapidae & & & & & \\
\hline 24 & Grey-winged Blackbird & Turdus boulboul & $\mathrm{R}$ & 0.00 & 1.18 & 0.00 \\
\hline 25 & Eurasian Blackbird & Turdus merula & V & 0.00 & 4.20 & 1.95 \\
\hline 26 & Blue Whistling Thrush & Myophonus caeruleus & $\mathrm{R}$ & 0.00 & 0.00 & 1.29 \\
\hline 27 & Dark-sided Flycatcher & Muscicapa striata & S & 1.98 & 2.87 & 0.00 \\
\hline 28 & Ferruginous Flycatcher & Muscicapa ferruginea & S & 0.00 & 1.95 & 0.00 \\
\hline 29 & Little Pied Flycatcher & Ficedula westermanni & S & 0.00 & 0.97 & 0.00 \\
\hline 30 & Verditer Flycatcher & Eumyias thalassina & $S$ & 24.4 & 3.50 & 0.70 \\
\hline 31 & Small Niltava & Niltava magrigoriae & $\mathrm{R}$ & 1.95 & 1.95 & 0.00 \\
\hline 32 & Rufous-bellied Niltava & Niltava sundara & $\mathrm{S}$ & 0.00 & 4.20 & 0.00 \\
\hline
\end{tabular}




\begin{tabular}{|c|c|c|c|c|c|c|}
\hline & Family / Common name & Scientific name & Status & SA - 1 & SA - 2 & SA - 3 \\
\hline 33 & Pale Blue Flycatcher & Cyornis unicolor & $\mathrm{R}$ & 0.00 & 4.20 & 0.00 \\
\hline 34 & Pigmy Blue Flycatcher & Muscicapella hodgsoni & $\mathrm{R}$ & 0.00 & 1.95 & 0.00 \\
\hline 35 & White-browed Bush Robin & Tarsiger indicus & $\mathrm{R}$ & 0.00 & 0.00 & 1.95 \\
\hline 36 & White-capped Water Redstart & Chaimarrornis leucocephalus & RB & 0.00 & 1.95 & 0.00 \\
\hline 37 & Plumbeous Water Redstart & Rhyacornis fuliginosus & RB & 0.00 & 1.95 & 0.00 \\
\hline 38 & White-tailed Robin & Myiomela leucura & $\mathrm{R}$ & 1.95 & 4.20 & 0.00 \\
\hline 39 & Golden Bush Robin & Tarsiger chrysaeus & $\mathrm{R}$ & 1.95 & 0.00 & 0.00 \\
\hline 40 & Pied Bushchat & Saxicola caprata & V & 6.56 & 6.56 & 0.00 \\
\hline \multirow[t]{2}{*}{41} & Grey Bushchat & Saxicola ferrea & RB & 2.55 & 5.26 & 1.95 \\
\hline & Sturnidae & & & & & \\
\hline 42 & Common Myna & Acridotheres tristis & $\mathrm{R}$ & 0.00 & 0.00 & 11.00 \\
\hline \multirow[t]{2}{*}{43} & Hill Myna & Gracula religiosa & $\mathrm{R}$ & 0.00 & 0.00 & 2.87 \\
\hline & Sittidae & & & & & \\
\hline 44 & White-tailed Nuthatch & Sitta himalayensis & $\mathrm{R}$ & 0.70 & 1.40 & 0.00 \\
\hline 45 & Beautiful Nuthatch & Sitta formosa & V & 0.00 & 1.95 & 0.00 \\
\hline \multirow[t]{2}{*}{46} & Rusty-flanked Treecreeper & Certhia nipalensis & $\mathrm{R}$ & 0.00 & 3.98 & 0.00 \\
\hline & Remizinae & & & & & \\
\hline \multirow[t]{2}{*}{47} & Fire-capped Tit & Cephalopyrus flammiceps & RB & 0.00 & 1.95 & 0.00 \\
\hline & Paridae & & & & & \\
\hline 48 & Green Back Tit & Parus major & $\mathrm{R}$ & 0.00 & 6.56 & 0.00 \\
\hline \multirow[t]{2}{*}{49} & Great Tit & Parus monticolus & $\mathrm{R}$ & 19.16 & 3.68 & 0.00 \\
\hline & Aegithalidae & & & & & \\
\hline \multirow[t]{2}{*}{50} & Black-throated Tit & Aegithalos concinnus & $\mathrm{R}$ & 1.95 & 0.00 & 0.00 \\
\hline & Hirundinidae & & & & & \\
\hline 51 & Barn Swallow & Hirudo rustica & $\mathrm{S}$ & 0.00 & 11.76 & 3.10 \\
\hline \multirow[t]{2}{*}{52} & Wire-tailed Swallow & Hirudo smithii & V & 0.00 & 0.70 & 0.00 \\
\hline & Pycnonotidae & & & & & \\
\hline 53 & Crested Finchbill & Spizixos canifrons & V & 0.00 & 1.95 & 0.00 \\
\hline 54 & Striated Bulbul & Pycnonotus striatus & $\mathrm{R}$ & 0.00 & 0.70 & 0.00 \\
\hline 55 & Red-vented Bulbul & Pycnonotus cafer & $\mathrm{R}$ & 0.00 & 2.55 & 5.12 \\
\hline \multirow[t]{2}{*}{56} & Black Bulbul & Hypsipetes leucocephalus & $\mathrm{R}$ & 0.00 & 1.70 & 0.00 \\
\hline & Cisticolidae & & & & & \\
\hline 57 & Plain Prinia & Prinia inornata & $\mathrm{R}$ & 0.00 & 1.18 & 0.00 \\
\hline \multirow[t]{2}{*}{58} & Bright-headed Cisticola & Cisticola exilis & $\mathrm{R}$ & 0.00 & 6.56 & 0.00 \\
\hline & Zosteropidae & & & & & \\
\hline \multirow[t]{2}{*}{59} & Oriental White Eye & Zosterops palpeprosus & $\mathrm{R}$ & 2.35 & 3.33 & 3.33 \\
\hline & Silvidae & & & & & \\
\hline 60 & Hoary-throated Barwing & Actinodura egertoni & $\mathrm{R}$ & 0.00 & 1.95 & 0.00 \\
\hline 61 & Blue-winged Minla & Minla cyanouroptera & $\mathrm{R}$ & 0.00 & 1.95 & 0.00 \\
\hline 62 & Chestnut-tailed Minla & Minla strigula & $\mathrm{R}$ & 2.22 & 3.41 & 0.00 \\
\hline 63 & Rufous-winged Fulvetta & Alcippe castaneceps & $\mathrm{R}$ & 0.00 & 4.20 & 0.00 \\
\hline 64 & Rufous-vented Yuhina & Yuhina occipitalis & $\mathrm{R}$ & 0.00 & 1.95 & 0.00 \\
\hline \multirow[t]{2}{*}{65} & Rufous sibia & Heterophasia capistrata & $\mathrm{R}$ & 6.56 & 4.57 & 0.00 \\
\hline & Nectarinidae & & & & & \\
\hline 66 & Mrs.Gould's Sunbird & Aethopyga gouldiae & $\mathrm{R}$ & 0.00 & 2.28 & 0.00 \\
\hline 67 & Green-tailed Sunbird & Aethopyga nipalensis & $\mathrm{R}$ & 0.00 & 1.18 & 0.00 \\
\hline
\end{tabular}




\begin{tabular}{|c|l|l|c|c|c|c|}
\hline & Family / Common name & Scientific name & Status & SA - 1 & SA - 2 & SA - 3 \\
\hline & Passeridae & & & & & \\
\hline 68 & House Sparrow & Passer domesticus & R & 0.00 & 0.00 & 8.14 \\
\hline 69 & Eurasian Tree Sparrow & Passer montanus & $\mathrm{R}$ & 0.00 & 9.72 & 0.00 \\
\hline 70 & Water Pipit & Anthus spinoletta & $\mathrm{V}$ & 0.00 & 6.56 & 0.00 \\
\hline & Fringillidae & & & & & \\
\hline 71 & Eurasian Siskin & Carduelis spinus & $\mathrm{V}$ & 1.86 & 4.21 & 0.00 \\
\hline 72 & Plain Mountain Finch & Leucosticte nemoricola & $\mathrm{V}$ & 0.00 & 9.00 & 0.00 \\
\hline 73 & Gold-naped Finch & Pyrrhoplectes epauletta & $\mathrm{R}$ & 14.00 & 0.00 & 0.00 \\
\hline & Total & & 130.39 & $\mathbf{1 7 2 . 5 3}$ & $\mathbf{6 9 . 3 2}$ \\
\hline
\end{tabular}

R - Residents; RB - Resident Breeding; S - Summer visitor; V - Vagrant

along a trekking corridor in the Sikkim Himalaya. Mountain Research and Development 25(3): 235-243.

Grimmett, R., C. Inskipp \& T. Inskipp (1998). Birds of the Indian Subcontinent. Oxford University Press, Delhi, 888pp.

Henderson, P.A. (2003). Practical Methods in Ecology. Blackwell Publishing, USA, vii+163pp.

Islam, M.Z. \& A.R. Rahmani (2004). Important Bird Area in India: Priority Sites for Conservation. IBCN, Bombay Natural History Society, BirdLife International, UK, xviii+1133pp.

IUCN (2011). IUCN Red List of Threatened Species. Version 2011.1. http://www.iucnredlist.org/. Accessed on 26 August 2011.
Kazmierczak, K. \& B.V. Perlo (2000). A Field Guide to The Birds of the Indian Subcontinent. Yale University Press, 352pp.

Pandya, P.J. \& K.D. Vachhrajani (2010). Birds of Mahi River estuary, Gujarat, India. Journal of Threatened Taxa 2(6): 994-1000.

Rodgers, W.A., H.S. Panwar \& V. B. Mathur (2002). Wildlife Protected Area Network in India: A Review (Executive summary). Wildlife Institute of India. Dehradun, 44pp.

Sutherland, W.J (2006). Ecological Census Techniques a handbook. Cambridge University Press, New York, 432pp. 